

\title{
Effects of Silver Reflective Mulch, White Inter-row Mulch, and Plant Density on Yields of Pepper in Maine
}

\author{
Mark G. Hutton ${ }^{1,3}$ and David T. Handley ${ }^{2}$
}

AdDitional INDEX WORDs. Capsicum annuum, bell pepper yield, plasticulture

SUMmARY. Bell peppers (Capsicum annumm) are an economically important yet difficult to grow crop in northern New England. Yields of bell peppers can be increased through the use of plastic mulches; however, refinements are needed to make bell peppers a more viable crop in regions with short, variable growing seasons. The objectives of this study were to (1) compare the effects of black mulch with white inter-row much, reflective silver mulch, and standard black plastic mulched beds on bell pepper yield and quality and (2) compare the effects of two in-row plant arrangements [single rows at 12 -inch within-row spacing (7260 plants/acre) and double rows spaced 18 inches apart with 18 -inch in-row spacing ( 9680 plants/acre)] on pepper yield and quality. Treatments were factorial combinations of three mulch treatments and two within-row planting arrangements. Double rows produced more fruit by number and weight than single rows; however, fruit harvested from the double-row plots tended to be smaller than fruit harvested from the single-row plots. Mulch treatments significantly influenced total marketable yield and yield of cull bell peppers grown in Maine. The plots receiving the inter-row white mulch or reflective silver mulch treatment produced significantly greater yield than standard black plastic mulch treatment. The reflective mulch treatment produced significantly more cull fruit per acre compared with the white inter-row mulch and black plastic.

Maine Agricultural and Forestry Experiment Station publication number 2930. This research was supported by U.S. Department of Agriculture Northeast Sustainable Agriculture Research and Education: On Farm Research/Partnership Project ONE05-041 and USDA Hatch Project ME08825-02, the Maine Vegetable and Small Fruit Growers Association, and the New England Vegetable and Berry Growers Association. Mention of a trademark, proprietary product, or vendor does not constitute a guarantee or warranty of the product, nor does it imply approval or disapproval to the exclusion of other products or vendors.

We thank Rick Belanger and Bryan Baggott for their assistance and support of this project.

${ }^{1}$ Department of Plant, Soil and Environmental Science, and University of Maine Cooperative Extension, Highmoor Farm, P.O. Box 179, Monmouth, Maine 04259

${ }^{2}$ University of Maine Cooperative Extension, Highmoor Farm, P.O. Box 179, Monmouth, Maine 04259 ${ }^{3}$ Corresponding author. E-mail: mhutton@umext. maine.edu.

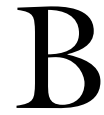
ell peppers are economically important yet difficult to grow in northern New England. Bell peppers are recognized to be environmentally sensitive, particularly with respect to flowering and fruit set (Quagliotti, 1979; Wien, 1997). Peppers grow best at soil temperatures between 20 and $30{ }^{\circ} \mathrm{C}$ (Gosselin and Trudel, 1986) and stable air temperatures between 18 and $30{ }^{\circ} \mathrm{C}$ (Maynard and Hotchmuth, 1997). Techniques are needed to enhance pepper maturity and yield to make this a more viable and profitable crop in northern New England and other regions characterized by short growing seasons and variable temperatures. Early and total yields of bell peppers can be increased through the use of plastic mulches, rowcovers, and low plastic tunnels (Alexander and Clough, 1998; Bowen and Frey, 2002; VanDerwerken and WilcoxLee, 1988; Wells and Loy, 1985). The increased yield of peppers and other crops grown on plastic mulch is generally attributed to increased soil temperatures. However, mulches can also effect the plant environment in other ways such as inhibition of weed growth, maintaining soil moisture, insect repellence, and selection of light wavelengths reflected back into the plant canopy (Decoteau et al., 1990; Greer and Dole, 2003; Ham et al., 1993; Tarara, 2000). Plastic mulches are now available in a range of types and colors, providing growers the opportunity to choose a mulch film best suited to a particular crop or growing conditions (Tarara, 2000). Clear mulches elevate soil temperatures more than opaque mulches, while reflective and lightcolored mulches tend to keep soil temperatures cooler compared with dark-colored mulches. White and reflective mulches also have the effect of changing the amount and quality of light reflected up into the plant canopy (Ham et al., 1993). Reflective mulches, such as aluminum foil and aluminum-painted plastic mulches, have had mixed results relative to increasing pepper yields compared

\begin{tabular}{llll}
\hline $\begin{array}{l}\text { Units } \\
\text { To convert U.S. to SI, } \\
\text { multiply by }\end{array}$ & U.S. unit & SI unit & $\begin{array}{l}\text { To convert SI to U.S., } \\
\text { multiply by }\end{array}$ \\
\hline 0.4047 & acre $(\mathrm{s})$ & $\mathrm{ha}$ & 2.4711 \\
0.0731 & $\mathrm{fl} \mathrm{oz} / \mathrm{acre}$ & $\mathrm{L} \cdot \mathrm{ha}^{-1}$ & 13.6840 \\
0.3048 & $\mathrm{ft}$ & $\mathrm{m}$ & 3.2808 \\
2.54 & inch $(\mathrm{es})$ & $\mathrm{cm}$ & 0.3937 \\
1.1209 & $\mathrm{lb} / \mathrm{acre}$ & $\mathrm{kg} \cdot \mathrm{ha}^{-1}$ & 0.8922 \\
0.0254 & mil & $\mathrm{mm}$ & 39.3701 \\
28.3495 & $\mathrm{oz}$ & $\mathrm{g}$ & 0.0353 \\
$\left({ }^{\circ} \mathrm{F}-32\right) \div 1.8$ & ${ }^{\circ} \mathrm{F}$ & ${ }^{\circ} \mathrm{C}$ & $\left(1.8 \times{ }^{\circ} \mathrm{C}\right)+32$
\end{tabular}


with black plastic mulch. Reflective mulches appear to lower insect infestations and reduce insect-transmitted diseases, although the overall effect on yield is unclear (Greer and Dole, 2003). Increased yield of bell peppers grown on aluminum-painted mulch was attributed to an increased amount of photosynthetically active radiation $(P A R)$ being reflected into the plant canopy (Porter and Etzel, 1982). Mulch surface colors that reflect light affect the growth of bell pepper plants by influencing the amount and quality of upwardly reflected light in addition to modifying soil temperature (Decoteau et al., 1990). To capitalize on the soilwarming characteristics of black mulch, in addition to the beneficial aspects of reflective mulch, agricultural plastic manufacturers have begun making printed or co-extruded aluminum on black films with 8 -inchwide black stripes where the plants are planted (Pliant, Schaumburg, Ill.). The intent of the black planting zone is to warm the soil in the immediate area around the seedlings.

The amount of light reflected into a plant canopy can also be altered with the use of plastic mulches placed between the planting beds. A recent study has shown that a high-density tomato (Lycopersicon esculentum) planting, grown on raised, black plastic mulched beds with white mulch covering the inter-row area between the beds had greater yields compared with the same tomato density on similar beds without the white interrow mulch. In fact, the high-density, 12 -inch within-row spacing and white inter-row mulch treatment produced $54 \%$ higher yields per unit area compared with the standard system of black mulch and 18 -inch within-row plant spacing (Ouellette and Loy, 2000).

The objectives of this study were to (1) compare the effects of black mulch with white inter-row much, reflective silver mulch, and standard black plastic mulched beds on bell pepper yield and quality and (2) compare the effects of two in-row plant arrangements on pepper yield and quality under these different mulch systems.

\section{Materials and methods}

The experiment was conducted at three locations in Maine: the
University of Maine, Highmoor Farm, Monmouth (lat. $44^{\circ} 14^{\prime} \mathrm{N}$, long. $70^{\circ} 04^{\prime} \mathrm{W}$ ), soil type Woodbridge fine sandy loam; a commercial vegetable farm located in Lewiston (lat. $43^{\circ} 55^{\prime} \mathrm{N}$, long. $70^{\circ} 07^{\prime} \mathrm{W}$ ), soil type Melrose fine sandy loam; and a commercial vegetable farm was in Readfield (lat. $44^{\circ} 21^{\prime} \mathrm{N}$, long. $69^{\circ} 55^{\prime} \mathrm{W}$ ), soil type Paxton-Charlton fine sandy loam.

Treatments were factorial combinations of three mulch treatments and two within-row planting arrangements. The following mulch treatments were applied by machine to 32 -inch-wide, 3 -inch-high raised beds on 6-ft centers: (1) blackembossed polyethylene mulch 0.07 mil thick, with SRM White mulch 0.07 mil thick (Kenbar, Reading, Mass.) applied after planting to the inter-row area between the black plastic raised beds; (2) reflective silver mulch with one or two 8-inch-wide black stripes (Heat Trap I and Heat Trap II, respectively; Reflectek Foils, Lake Zurich, Ill.); and (3) control treatment, black-embossed polyethylene mulch 0.07 mil thick (Kenbar). Treatments were arranged in a splitplot design with mulch treatments as the main plots and planting arrangement as subplots. The subplot treatments were in-row plant spacing and density treatment: (a) two rows of plants on a bed 16 inches apart and spaced 18 inches within rows $(9680$ plants/acre) and (b) a single row of plants spaced 12 inches within the row (7260 plants/acre). Plots were arranged in an identical randomized complete-block design with three replications at each site, resulting in a total of nine replications. Plots were $15 \mathrm{ft}$ long with guard rows planted in the beds on each side of treatment plot.

Fertilizer was applied at each site based on soil test recommendations before forming beds and laying the plastic mulch. No herbicides were applied at site one; the weeds were managed through cultivation. At site two, napropamide (2 lb/acre) was incorporated before application of the plastic mulch. Weeds were managed at site three by applying halosulfuron applied at $0.5 \mathrm{fl} \mathrm{oz} /$ acre between the rows of plastic.

'King Arthur' pepper transplants were grown by each farm for use in the experiment at that site. Field preparation and planting dates were determined by the growers at the participating farms. Sites one and three were planted on 15 June 2005, while site two was planted 5 June 2005. Each farm followed standard pest management practices recommended in the New England Vegetable Management Guide (Howell, 2004).

Fruit yields from each site were evaluated by harvesting all but the first and last plant on the single-row plots (13 harvested plants) or the first and last pair of plants in the doublerow plots (16 harvested plants). Four harvests were made at sites one (19 Aug., 25 Aug., 9 Sept., 21 Sept.) and four at site three (18 Aug., 26 Aug., 2 Sept., 14 Sept.). A total of six harvests were made at site two (4 Aug., 10 Aug., 18 Aug., 26 Aug., 2 Sept., and 19 Sept.). Harvests before 1 Sept. were considered early harvest. All fruit of marketable size were harvested by hand and graded as marketable or cull. Fruit with poor shape, sunscald, blossom end rot, insect damage, and disease were graded as culls. Fruit from each plot were counted and weighed at each harvest. Early marketable yield, marketable yield, and cull yield were summed for all harvests and expressed on a per acre basis.

Soil temperatures were measured using two temperature probes (HOBO U12 and TMC-50HD temperature probes; Onset Computer, Bourne, Mass.) placed in one plot of each mulch treatment plot in the center of each bed $\approx 10 \mathrm{~cm}$ deep. Temperature data were collected hourly beginning 1 June and continued through 23 Sept. Average hourly soil temperature was calculated over the entire growing season.

\section{Results and discussion}

Temperature. Small differences were seen in soil temperature among the mulch treatments (Fig. 1). Diurnal soil temperatures were slightly warmer in the beds mulched with reflective mulch compared with black mulch with and without the inter-row mulch. Generally, soil temperatures are cooler under silver mulch compared with black mulch (Ham et al., 1993); in contrast, Gough (2001) found no differences in soil temperature at a depth of $5 \mathrm{~cm}$ in beds 


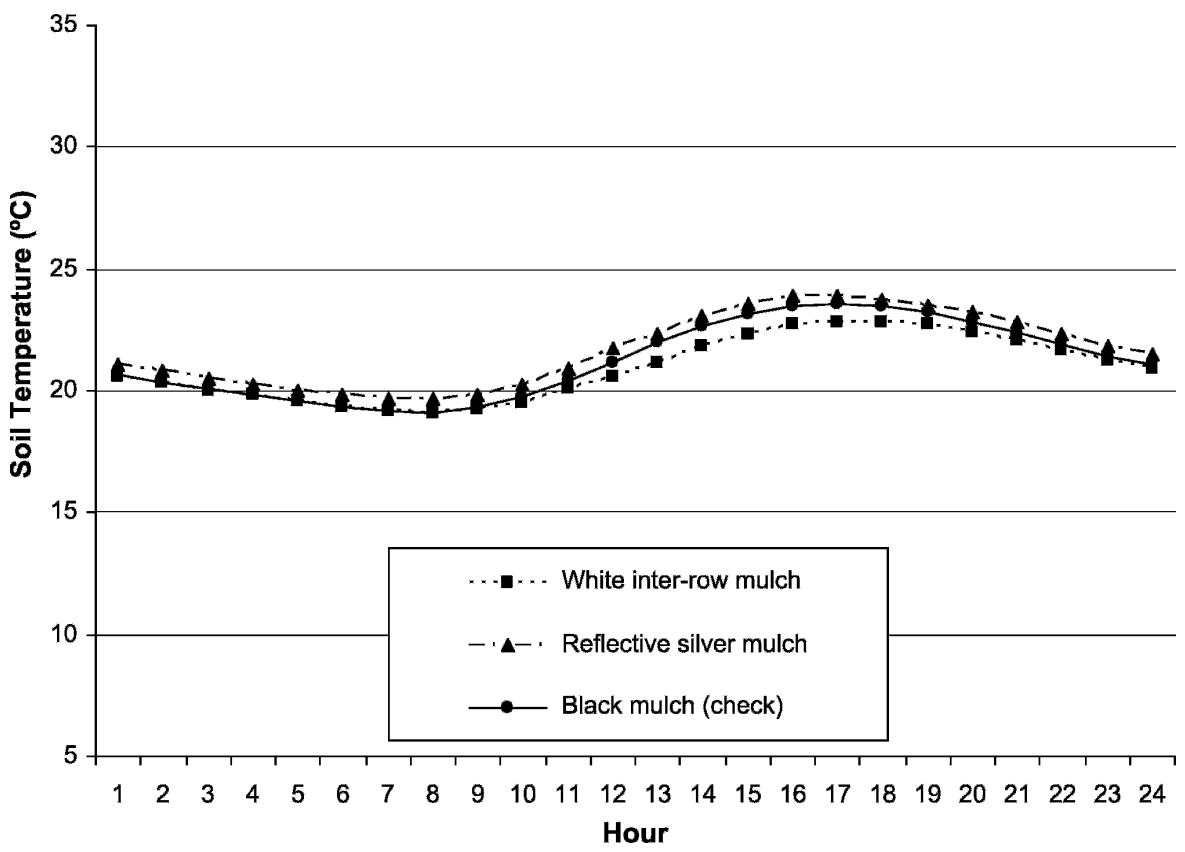

Fig. 1. Average hourly soil temperature measured at $10 \mathrm{~cm}(3.9$ inches $)$ below soil surface. Values are hourly averages from 1 June to 23 Sept. 2005 at University of Maine, Highmoor Farm, Monmouth; $\left(1.8 \times{ }^{\circ} \mathrm{C}\right)+32={ }^{\circ} \mathrm{F}$.

covered with either black or silver mulch. Ham et al. (1993) examined the optical properties of several mulches and determined that silver mulch would absorb less shortwave and longwave radiation compared with black, but would also emit less longwave radiation, potentially making it a better insulator, trapping more soil heat compared with black mulch. It is possible the combination of the black stripe on the silver mulch combines the properties of both plastics to achieve the warmer soil temperatures observed.

Marketable Yield. Pepper yields were significantly different among the three farms in this study (Table $\mathrm{l}$ ). This is not surprising given the differences in the farm location, field cropping history, and differences in planting and harvest dates. However, there were no significant interactions between farms and the mulch or plant density treatments. There was a significant interaction between farm and planting density for early yield. However, by the end of the season the interaction was nonsignificant and was probably due to age and size of transplants.

Double plant rows with 18 -inch spacing produced significantly more fruit by number and weight than single plant rows at 12 -inch spacing for early and total marketable harvest (Table 2). This result agrees with other work in which higher planting densities of pepper increased yields (Locascio and Stall, 1994). The 9\% yield increase observed under the higher plant density, however, was not proportional to the $33 \%$ increase in plant numbers for the double rows, likely a result of increased interplant competition at the higher density. Higher plant densities also tended to produce smaller fruit and a higher number of culls (Table 3 ).

There were no significant interactions between mulch treatment and plant density (Table 1 ). However, it is interesting to note that the yield of single-row peppers in the white interrow mulch treatment $(51,085$ fruit/ acre and 20,353 lb/acre) was similar to the yield of double-row peppers from the standard black plastic mulch plots $(52,345$ fruit/acre and 19,913 $\mathrm{lb} / \mathrm{acre})$. However, the single-row treatment had $25 \%$ fewer plants than the double rows per acre.

Early marketable yield accounted for $25 \%$ to $27 \%$ of the total marketable yield. Earliness was not significantly affected by the three mulch treatments (Table l).

The inter-row white and reflective silver mulch treatments produced significantly more marketable fruit than the black mulch control (Table $2)$. The number of fruit harvested from the inter-row mulch plots was $21 \%$ greater than the amount harvested from the control treatment and $18 \%$ greater than from the silver mulch treatment. These results agree with results obtained in preliminary experiments (Hutton et al., 2005) and similar research with tomato (Ouellette and Loy, 2000), indicating white inter-row mulch increased yield compared with black plastic mulch alone. We were unsuccessful in measuring light levels within the plant canopy. However, Ouellette reported (2005) a $3 \times$ increase in the amount of light reflected back up into the plant canopy in rows with white inter-row mulch compared with black mulched beds without inter-row mulch. It seems reasonable to expect the yield increase observed from the white inter-row mulch and reflective silver mulch treatments could be attributed to the increased amount of light reflected into the plant canopy.

Studies have documented mixed results on the effects of reflective and silver mulch on pepper yield. In some cases, increased yields occurred (Black and Rolston, 1972; Porter and Etzel, 1982); in other cases, no yield increases were detected (Kring and Schuster, 1992). One advantage of reflective mulches is the reduction of aphid-transmitted virus diseases and increased yields due to lower incidence of insect-transmitted virus (Greer and Dole, 2003). However, in northern New England, insectvectored viruses are not typically a concern. In the study by Porter and Etzel (1982) where insect-vectored viruses were not a problem, aluminum painted plastic mulch resulted in higher yields of bell pepper compared with black plastic. However, in only 1 of 2 years were the differences statistically significant. The authors concluded that the yield increase was probably due to increased light being reflected into the plant canopy.

Cull YIELD. There were no significant differences in cull yield among the mulch treatments. The percentage of harvest fruit culled was generally low. Nineteen percent of the fruit harvested from the silver mulch were culled, followed by $14 \%$ for the control treatment and $11 \%$ 




for the inter-row mulch treatment. The most frequent reason for culling fruit was sunscald. The incidence of sunscald was significantly different among the three mulch treatments. The white inter-row mulch treatment had the highest percentage of sunscald followed by the reflective mulch and the black mulch control. Sunscald occurs when fruit are exposed to high levels of sunlight and the fruit surface heats to the point of damaging the cells (Wien, 1997). Exposure of the fruit to high light levels can result from poor foliage cover (VanDerwerken and WilcoxLee, 1988) or exposure to high light levels (Robert and Anderson, 1994). Silver reflective mulch (Ham et al., 1993 ) and white inter-row mulch (Ouellette, 2005) have been shown to increase light levels within the plant canopy and may have resulted in increased sunscald observed in this study. In this study, we observed significantly fewer insect damaged fruit harvested from the reflective mulch treatments compared with the black mulch control treatment (Table 3 ). This agrees with the findings of Greer and Dole (2003) demonstrating that reflective mulches have been shown to reduce insect damage. Other defect categories accounted for less than $20 \%$ of the cull fruit and are probably unimportant.

Weed control through the use of plastic mulch is an oft-cited benefit of using mulches (Ngouajio and Ernest, 2004). In this study, the use of the white inter-row mulch expanded the benefit of weed control into the row middles. The two growers participating in this study were impressed by the additional benefit of weed control as a result the inter-row mulch treatment covering the area between the raised beds. These preliminary data suggest that white inter-row mulches can be used by bell pepper growers to achieve greater yields compared with the standard practice of using only black plastic. Growers should exercise caution, however, because these results are for 1 year only with only the total numbers of fruit affected. Further research in this area is warranted. Finally, growers should be cautioned that there are potential disadvantages to the system, such as an increase in the amount of sunscald resulting from the reflective mulches. 
Table 2. Early, total marketable yield, and fruit size of 'King Arthur' bell peppers grown using different mulch treatments and plant arrangements.

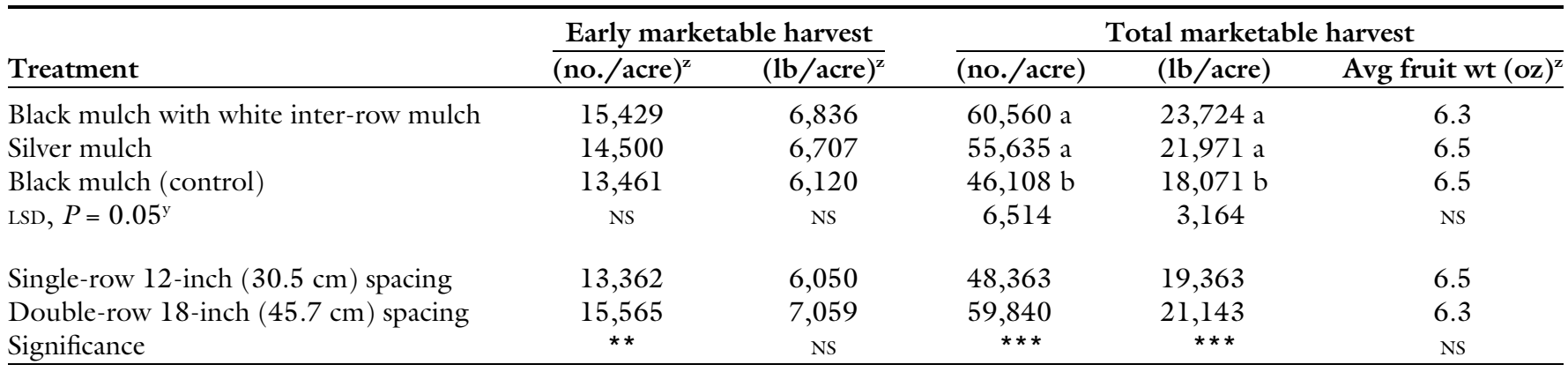

${ }^{\mathrm{z}} \mathrm{l}$ fruit $/$ acre $=2.47 \mathrm{ll}$ fruit $/ \mathrm{ha}, \mathrm{l} \mathrm{lb} / \mathrm{acre}=1.1209 \mathrm{~kg} \cdot \mathrm{ha}^{-1}, \mathrm{l} \mathrm{oz}=28.3495 \mathrm{~g}$.

${ }^{y}$ Means not followed by the same letter are significantly different with least significant difference (LSD) at $P=0.05$

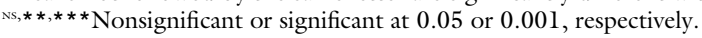

Table 3. Cull yield and classification of 'King Arthur' bell peppers grown using different mulch treatments and plant arrangements.

\begin{tabular}{|c|c|c|c|c|c|c|c|}
\hline \multirow[b]{2}{*}{ Treatment } & \multicolumn{2}{|c|}{ Total cull harvest } & \multicolumn{5}{|c|}{ Classification of cull fruit (\% of culls) } \\
\hline & (no./acre $)^{\mathrm{z}}$ & $(\mathrm{lb} / \mathrm{acre})^{\mathrm{z}}$ & Poor shape & Blossom end rot & Sunscald & Insect damage & Disease \\
\hline $\begin{array}{l}\text { Black mulch with white } \\
\text { inter-row mulch }\end{array}$ & 7,733 & 2,946 & $16 \mathrm{~b}$ & $10 \mathrm{~b}$ & $49 \mathrm{a}$ & $7 \mathrm{~b}$ & 18 \\
\hline Silver mulch & 11,485 & 3,851 & $19 \mathrm{a}$ & $18 \mathrm{a}$ & $35 \mathrm{~b}$ & $8 \mathrm{~b}$ & 20 \\
\hline Black mulch (control) & 8,510 & 2,814 & $14 \mathrm{~b}$ & $15 \mathrm{~b}$ & $30 \mathrm{c}$ & $18 \mathrm{a}$ & 23 \\
\hline $\mathrm{LSD}, P=0.05^{\mathrm{y}}$ & NS & NS & 2.7 & 3.6 & 3.3 & 2.6 & NS \\
\hline $\begin{array}{l}\text { Double-row } 18 \text {-inch } \\
\quad(45.7 \mathrm{~cm}) \text { spacing }\end{array}$ & 11,036 & 3,766 & 19 & 15 & 33 & 12 & 21 \\
\hline Significance & $* * *$ & $* * *$ & $* * *$ & & $* * *$ & ** & NS \\
\hline
\end{tabular}

${ }^{\mathrm{z}} 1$ fruit $/$ acre $=2.4711$ fruit $/ \mathrm{ha}, 1 \mathrm{lb} / \mathrm{acre}=1.1209 \mathrm{~kg} \cdot \mathrm{ha}^{-1}$.

${ }^{y}$ Means not followed by the same letter are significantly different with least significant difference (LSD) at $P=0.05$.

$\mathrm{Ns}, * *, * * *$ Nonsignificant or significant at 0.05 or 0.001 , respectively.

\section{Literature cited}

Alexander, S. and G.H. Clough. 1998. Spunbonded rowcover and calcium fertilization improve quality and yield and bell pepper. HortScience 33(7):1150-1152.

Black, L.L. and R.H. Rolston. 1972. Aluminum foil mulch reduces virus infection of peppers. Louisiana Agr. 15(4):6-7.

Bowen, P. and B. Frey. 2002. Response of plasticultured bell pepper to staking, irrigation frequency, and fertigated nitrogen rate. HortScience 37(1):95-100.

Decoteau, D.R., M.J. Kasperbauer, and P.G. Hunt. 1990. Bell pepper plant development over mulches of diverse colors. HortScience 25(4):460-462.

Gosselin, A. and M.J. Trudel. 1986. Root-zone temperature effects on pepper. J. Amer. Soc. Hort. Sci. 111:220224.

Gough, R.E. 2001. Color of plastic mulch affects lateral root development but not root system architecture in pepper. HortScience 36(1):66-68.

Greer, L. and J.M. Dole. 2003. Aluminum foil, aluminum-painted, plastic and degradable mulches increase yields and decrease insect-vectored viral diseases of vegetables. Hort Technology 13(2):276284.

Ham, J.M., G.J. Kluitenberg, and W.J. Lamont. 1993. Optical properties of plastic mulches affect the field temperature regime. J. Amer. Soc. Hort. Sci. 228(2): 188-193.

Howell, J. (ed.) 2004. 2004-2005 New England vegetable management guide. New England Ext. Systems, University of Massachusetts, Amherst.

Hutton, M.G., D.T. Handley, and T.L. Jackson. 2005. Evaluation of reflective mulch and white inter-row mulch for increasing yields of bell pepper. Natl. Agr. Plastics Congr. Proc. 32:76-78.

Kring, J.B. and D.J. Schuster. 1992. Management of insects on pepper and tomato with UV-reflective mulches. Fla. Entomol. 75:119-129.

Locascio, S.J. and W.M. Stall. 1994. Bell pepper yield as influenced by plant spacing and row arrangement. J. Amer. Soc. Hort. Sci. 119:899-902.

Maynard, D.N. and G.J. Hotchmuth. 1997. Knott's handbook for vegetable growers, 4th ed. Wiley, New York.

Ngouajio, M. and J. Ernest. 2004. Light transmission through colored polyethylene mulches affects weed populations. HortScience 39(6):1302-1304.

Ouellette, A. 2005. Effects of reflective interrow mulch and plant density on yield of fresh market tomato. M.S. Thesis, University of New Hampshire, Durham.

Ouellette, A. and J.B. Loy. 2000. Effect of plant density and reflective polyethylene mulch treatments on growth and yield of tomato. Natl. Agr. Plastics Congr. Proc. 29:279-291. 
Porter, W.C. and W. Etzel. 1982. Effects of aluminum-painted and black polyethylene mulches on bell pepper, Capsicum annuum L. HortScience 17(6): 942-943.

Quagliotti, L. 1979. Floral biology of Capsicum and Solanom melogena, p. 339-416. In: J.G. Hawkes (ed.). The biology and taxonomy of the Solanaceae. Academic Press, New York.
Robert, B.W. and J.A. Anderson. 1994. Canopy shade and soil mulch affect yield and solar injury of bell pepper. HortScience 29(4):258-260.

Tarara, J.M. 2000. Microclimate modification with plastic mulch. HortScience 35(2):169-180.

VanDerwerken, J.E. and D. Wilcox-Lee. 1988. Influence of plastic mulch and type and frequency of irrigation on growth and yield of bell pepper. HortScience 23(6):985-988.

Wells, O.S. and J.B. Loy. 1985. Intensive vegetable productions with row covers. HortScience 20(5):822-826.

Wien, C.H. 1997. Peppers, p. 259-293. In: H.C. Wien (ed.). The physiology of vegetable crops. CAB Intl, New York. 